\title{
PEMBUATAN MEDIA PEMBELAJARAN VIDEO INTERAKTIF MENGGUNAKAN ADOBE FLASH UNTUK MENINGKATKAN KEMAMPUAN BELAJAR IPA SISWA SD TUNARUNGU SLB
}

\author{
Vita Krisnita $^{1)}$, Muhammad Taufiq ${ }^{2)}$, Alfadl Habibie ${ }^{3)}$ \\ ${ }^{1,2,3)}$ Pendidikan Teknnologi Informasi Universitas Muhammadiyah Tasikmalaya \\ Email: vitakrisnita18@gmail.com ${ }^{l)}$ mtaufiq@umtas.ac.id ${ }^{2)}$ Alfadl@umtas.ac.id $^{3)}$
}

\begin{abstract}
ABSTRAKSI
Kemajuan yang paling menonjol dalam perkembangan TIK dan akan memasuki era penting dalam kehidupan sehari-hari adalah di bidang multimedia dengan upaya mengkonvergensikan audio dan video menjadi satu kesatuan yang tidak terpisahkan. Jenis penelitian ini menggunakan penelitian kualitatif dengan desain Research and Development menggunakan metode Waterfall dengan populasi peserta didik kelas IV B Tunarungu dan sample terdiri dari 10 peserta didik kelas IV B tunarungu. Manfaat adanya media ini dapat membantu meningkatkan kemampuan belajar peserta dengan hasil pembelajaran nilai rata rata peserta didik yang awalnya hanya 70,52 mengalami peningkatan yang baik menjadi 87,89 Secara keseluruhan menurut para ahli media menunjukkan bahwa media ini masuk dalam kategori sangat baik dengan rata-rata $82,5 \%$ dengan 7 orang mengalami peningkatan kemampuan belajar, 2 orang mengalami peningkatan yang rendah dan 1 orang tidak mengalami peningkatan sama sekali. Berdasarkan hasil yang didapat dari media pembelajaran ini layak digunakan untuk mendukung kegiatan belajar mengajar siswa kelas IV tunarungu SDLB Aisiyah Kawalu Tasikmalaya.
\end{abstract}

Kata kunci: Media pembelajaran interaktif, kemampuam belajar, tunarungu.

\begin{abstract}
The most prominent progress in the development of ICT and will enter an important era in life daily activities are in the field of multimedia with efforts to converge audio and video into one unit inseparable. This type of research uses qualitative research with a Research and Development design using the Waterfall method with a population of class IV B students with hearing impairment and a sample consisting of 10 class IV B students who are deaf. The benefits of this media can help improve the learning ability of participants with the learning outcomes of the average value of students who were initially only 70.52 experienced a good increase to 87.89 Overall according to media experts, it shows that this media is in the very good category with an average of $82.5 \%$ with 7 people experiencing increased learning abilities, 2 people experienced a low increase and 1 person did not experience an increase at all. Based on the results obtained from this learning media, it is suitable to be used to support teaching and learning activities for class IV deaf students of SDLB Aisiyah Kawalu, Tasikmalaya.
\end{abstract}

Keywords: Interactive learning media, learning ability, deaf.

\section{PENDAHULUAN}

Pada hakikatnya pada proses belajar mengajar merupakan sebuah sistem, yang didalamnya memiliki berbagai komponen yang saling bekerja sama dan terpadu untuk mencapai tujuan pembelajaran. Komponen-komponen tersebut adalah tujuan pengajaran, guru dan peserta didik, bahan pelajaran, metode dan strategi belajar mengajar, alat atau media, sumber pelajaran dan evaluasi. Media pembelajaran merupakan alat dan penyampaian informasi atau pesan pembelajaran pada peserta didik, dengan adanya media pada proses belajar mengajar, diharapkan dapat membantu guru dalam meningkatkan prestasi belajar pada siswa. Maksud dari penelitian ini memberikan ide mengenai tambahan media pembelajaran menggunakan video interaktif, karena dari hasil pengamatan pada penelitian sebelumnya, media pembelajaran yang digunakan di SLB belum optimal dikarenakan tidak semua siswa tunarungu mengerti dengan media pembelajaran jika hanya menggunakan bahasa isyarat saja. Oleh karena itu, peneliti bermaksud memberi solusi kepada guru agar pembelajaran anak tunarungu lebih maksimal, karena dengan media video interaktif meskipun siswa tunarungu tidak bisa mendengar, tetapi mereka dapat mengamati video pembelajaran yang didalamnya terdapat teks 
yang dapat dibaca oleh anak tunarungu tersebut. Aplikasi yang ditawarkan peneliti pada guru yaitu menggunakan Adobe Flash karena aplikasi Adobe flash menyediakan fitur yang menarik dan cara pengerjaannya tergolong mudah.

Menurut Trianto [6] menjelaskan bahwa pembelajaran merupakan aspek kegiatan manusia yang kompleks yang tidak sepenuhnya dapat dijelaskan. Pembelajaran secara mudah dapar diartikan sebagai produk interaksi berkelanjutan antara pengembangan dan pengalaman hidup Pembelajaran memiliki beberapa komponen pendukung didalamnya yaitu tujuan pembelajaran, materi pembelajaran, dan kegiatan pembelajaran. Dalam proses pembelajaran, Muhson [2] menjelaskan bahwa banyak media-media yang digunakan untuk memudahkan proses belajar. Bila berada di dalam kelas, untuk menyampaikan pembelajaran guru akan memanfaatkan beberapa peralatan seperti gambar, model, atau alat lainnya. Pada dasarnya jenis dan bentuk media ada banyak sekali. beberapa jenis media yaitu media audio, media visual, dan media audio visual.

Menurut Sari, Sangsoko [7] Media Interaktif adalah alat bantu berbasis multimedia yang bisa menyampaikan pesan atau informasi dari guru ke siswa yang dalam prosesnya terjadi komunikasi aktif dua arah antara multimedia dengan pengguna atau yang tujuannya untuk mempermudah proses pembelajaran. Media interaktif juga media yang menggabungkan teks, grafik, video, animasi dan suara. Untuk menyampaikan suatu pesan dan informasi, melalui media elektronik seperti komputer dan perangkat elektronik lainnya.

Menurut Roblyer dan Doering 2010:175-176 dalam Ningsih [3] Terdapat banyak model multimedia interaktif yang digunakan untuk tujuan pembelajaran, diantaranya:

\section{Tutorial}

Model tutorial adalah yaitu suatu jenis model pembelajaran yang memuat penjelasan, rumus, prinsip, bagan, tabel, definisi istilah, latihan dan branching yang sesuai. Disebut branching karena terdapat berbagai cara untuk berpindah melalui pembelajaran berdasarkan respon pengguna terhadap materi, soal-soal atau pertanyaan-pertanyaan. Jenis ini melibatkan presentasi informasi. Tutorial secara khusus terdiri dari diskusi mengenai konsep atau prosedur dengan pertanyaan bagian demi bagian atau kuis pada akhir presentasi

2. Drill and practice

Model drill and practice merupakan konsep dasar telah dikuasai oleh pengguna dan mereka yang siap untuk menerapkan rumus-rumus, bekerja dengan kasus-kasus konkret, dan menjelajahi daya tangkap mereka terhadap materi. Fungsi utama latihan dan praktik dalam program pembelajaran berbantuan komputer memberikan praktik sebanyak mungkin terhadap kemampuan siswa.

3. Simulasi

Simulasi dengan situasi kehidupan nyata yang dihadapi pengguna, yang dimaksudkan untuk memperoleh pengertian global tentang proses. Simulasi digunakan untuk memperagakan sesuatu (keterampilan) sehingga pengguna merasa seperti berada dalam keadaan yang sebenarnya. Simulasi banyak digunakan pada pembelajaran materi yang membahayakan, sulit, atau memerlukan biaya tinggi, misalnya untuk melatih pilot pesawat terbang.

Manfaat Multimedia Interaktif dalam bidang Pendidikan / Khususnya Pembelajaran adalah sebagai berikut:

1. Proses pembelajaran lebih menarik,

2. Lebih interaktif,

3. Jumlah waktu mengajar dapat dikurangi,

4. Kualitas belajar dapat ditingkatkan, dan proses belajar mengajar dapat dilakukan dimana dan kapan saja, serta

5. Sikap belajar siswa dapat ditingkatkan.

Berdasarkan pendapat yang dikemukakan oleh Setia, Santi, Kurniawan [8] Adobe Flash atau yang dikenal pada awalnya sebagai Macromedia Flash adalah salah satu perangkat lunak komputer yang merupakan produk unggulan dari Adobe Systems. Dalam buku Haenudin kutipan Donald F. Morees dan Tati Hernawati [1] Mendefinisikan Tunarungu adalah suatu istilah umum yang menunjukan kesulitan mendengar dari yang ringan sampai berat digolongkan ke dalam tuli dan kurang dengar. Orang tuli adalah yang kehilangan kemampuan mendengar sehingga menghambat proses informasi bahasa melalui pendengara, baik memakai ataupun ataupun tidak memakai alat bantu dengar. Sedangkan yang dikatakan kurang dengar adalah mereka yang apabila menggunakan alat bantu mendengar sisa pendengarannya cukup memungkinkan keberhasilan dalam proses memperoleh informasi bahasa melaui pendengarannya.Berikut ini adalah jenis jenis Ketunarunguan yang terdapat pada buku Haenudin [1] : 
1. Tunarungu Hantaran (Konduksi) yaitu ketunarunguan yang disebabkan oleh kerusakan atau tidak berfungsinya alat alat penghantar getaran suara pada telinga bagian teaungah. Ketunarunguan konduksi terjadi karena pengurangan tingkatan bunyi yang mencapai telinga bagian dalam, dimana syaraf pendengaran berfungsi.

2. Tunarungu Syaraf (Sensorineural), yaitu ketunarunguan yang disebabkan oleh kerusakan atau tidak berfungsinya alat alat pendengaran bagian dalam syaraf pendengaran yang menyalurkan getaran ke pusat pendengaran pada Lobus Temporalis.

3. Tunarungu Campuran, yaitu ketunarunguan yang disebabkan kerusakan pada penghantar suara dan kerusakan pada syaraf pendengaran

\section{METODE PENELITIAN}

Penelitian ini merupakan jenis penelitian deskriptif kualitatif dengan desain Research and Development $(R n D)$ dengan menggunakan metode waterfall.

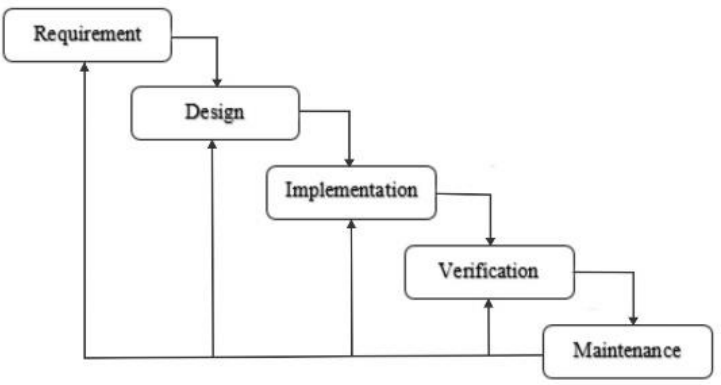

Gambar 1. Skema metode waterfall

Berikut ini langkah-langkah metode penelitian waterfall sebagai berikut :

1. Reqirement (Kebutuhan)

Dalam hal ini memerlukan definisi yang jelas terkait tujuan pengembangan sistem, harapan dari pengembangan sistem ini, dan hasil akhir dari pengembangan multimedia interaktif perubahan wujud benda ini diharapkan untuk memecahkan suatu masalah.

2. Desain

Tahap ini adalah pembuatan sketsa dari banyak elemen-elemen yang terpisah, dan dijadikan dalam satu kesatuan utuh yang nantinya dapat difungsikan. Jadi tahap ini harus di dokumentasikan sebagai konfigurasi dari software. Adapun tahap yang dilakukan dalam perancangan meliputi materi yang akan dimasukan kedalam media, pembuatan flowchart untuk menggambarkan alur dan storyboard sebagai deskripsi gambar media.

3. Implementasi

Implementasi ini tahap yang dilakukan setelah semua proses desain, perancangan kontainer data dan bahasa pemrograman sebagaimana telah diuraikan diatas. Tujuan yang akan dicapai pada tahap ini adalah dapat dioperasikannya hasil pengembangan ini. Tahap ini juga menjelaskan mengenai sistem yang dirancang serta cara penggunaan aplikasi multimedia interaktif perubahan wujud benda ini.

4. Verifikasi dan Validasi

Merupakan tahap pengujian dari pengembangan suatu sistem. Pada proses ini aplikasi akan diujikan kepada ahli media yang menguasai dalam bidang ini dan diujikan kepada user. Dimana hasil dari tahap ini akan dijadikan pedoman dalam pemberian keputusan apakah layak atau tidak aplikasi ini digunakan peserta didik.

5.Maintenance atau Pemeliharaan

Tahap ini terjadi setelah akhir dari pengembangan sistem telah diuji dan disetujui oleh penguji. Tahap ini merupakan tahap dimana aplikasi ini akan dimodifikasi atau dilakukan proses pemeliharaan.

Penelitian dan pengembangan ini menggunakan metode Observasi. Tes dan Non Tes. Observasi dilakukan di SDLB Aisiyah Kawalu diruangan kelas IV B Tunarungu, Tes yang digunakan dalam penilaian ini menggunakan pretes dan postes dengan kompetensi dasar membedakan berbagai perubahan wujud benda berdasarkan penyebabnya dengan menggunakan 10 soal pilihan ganda dan 3 soal essay dan non tes berupa angket validasi materi dan validasi media 
dengan menggunakan skala likert 5. Validasi angket ahli materi menggunakan 10 pernyataan sedangkan validasi angket ahli media menggunakan 8 pernyataan.

Analisis Data untuk mengetahui nilai dari validasi materi, validasi media dan validasi angket peserta didik menggunakan rumus menurut Nismalasari, Santiani, dan Rohmadi dalam Gito Supriadi [4] sebagai berikut :

$$
\text { Nilai }=\frac{\text { Score Yang Dicapai }}{\text { Score Maksimal Ideal }} \times 100
$$

Setelah Diketahui nilai dari hasil validasi materi dan validasi ahli media, kemudian ditentukan kategori kelayakan berdasarkan rumus interval yang dikemukakan oleh Sudjana [5] yaitu sebagai berikut :

$$
P \frac{\text { Rentang }}{\text { Banyak Kelas Intervasi }}
$$

Keterangan :

$\mathrm{P}=$ Panjang Kelas Interval

Rentang = Nilai tertinggi - Nilai terendah

Berdasarkan penjelasan dari Sudjana [5] tersebut diketahui bahwa persentase perolehan maksimal dalam penilaian keseluruhan yaitu 100\% sedangkan persentase nilai minimalnya adalah $1 \%$ maka dari itu diperoleh rentang sebesar 19.8 dan kelas interval yang akan dicantumkan untuk penilaian berjumlah 5 yaitu mulai dari yang terkecil sangat kurang, kurang, cukup baik, baik, dan sangat baik,

a. Analisis Data Hasil angket peserta didik

Angket peserta didik terdiri dari Pretest dan postest dengan menggunakan analisis data sebagai berikut:

Keterangan Penilaian sebagai berikut:

$$
\text { Nilai }=\frac{\text { Score Yang Dicapai }}{\text { Score Maksimal Ideal }} \times 100
$$

1.) Soal pilihan ganda terdiri dari 10 soal dengan bobot nilai persoal adalah 1.

2.) Soal essay terdiri dari 3 soal dengan bobot nilai persoal 3 .

3.) Jadi nilai maksimal ideal yaitu 19

4.) Kemudian, dicari nilai rata-rata dari keseluruhan responden yang diperoleh dari penjumlahan total nilai seluruh responden dibagi dengan jumlah responden.

\section{b. Analisis Data Uji Gain Ternormalisasi}

Sundayana [4] menjelaskan uji analisis untuk materi pembelajaran IPA mata pelajran perubahan wujud benda dan hasil belajar siswa menggunakan hasil pretest, posttes, gain dan N-gain. Gain merupakan nilai selisih antara nilai pretest dan posttest. Untuk menunjukkan kualitas peningkatan kemampuan belajar IPA dan hasil belajar siswa digunakan rumus rata-rata gain ternormalisasi. N-gain (normalized gain) digunakan untuk mengukur peningkatan keterampilan proses sains dan hasil belajar kognitif antara sebelum dan setelah pembelajaran. Untuk mengetahui $\mathrm{N}$-gain digunakan rumus sebagai berikut:

$$
N-\text { Gain }=\frac{\text { Skor Postest }- \text { Skor Pretest }}{\text { Skor Maks }- \text { Skor Pretest }} \times 100
$$

Tabel 1. Kriteria Persentase Gain Ternormalisasi

\begin{tabular}{|c|c|}
\hline Persentase & Klasifikasi \\
\hline N-gain $>70$ & Tinggi \\
\hline $30 \leq$ N-Gain $\leq 70$ & Sedang \\
\hline N-gain $<30$ & Rendah \\
\hline
\end{tabular}

Sumber: Archambault (Situmorang, Muhibudin., Khairil, 2015: 88) 


\section{HASIL DAN PEMBAHASAN}

1. Deskripsi Hasil Pembuatan Media Pembelajaran Interaktif

Hasil akhir yang diperoleh dari penelitian pengembangan ini adalah sebuah media pembelajaran interaktif tentang perubahan wujud benda. Pada tahapan pengembangan media pembelajaran digunakan model waterfall yang terdiri dari 5 tahapan dan akan dijelaskan sebagai berikut:

\section{a. Requirement}

Requirement menjadi tahap awal dan berperan penting dalam penggunaan metode waterfall. Pengumpulan informasi mengenai kebutuhan sistem yang akan dibangun dan kebutuhan yang nantinya akan dijadikan solusi bagi pengguna. Maka dari itu dengan diberikannya media pembelajaran interaktif ini dapat membantu menarik minat belajar siswa khususnya dalam mata pelajaran IPA. Dalam hal ini memerlukan definisi yang jelas terkait tujuan pembuatan media pembelajaran, harapan dari pengembangan media, dan hasil akhir dari pengembangan multimedia interaktif perubahan wujud benda ini diharapkan menjadi solusi media pembelajaran bagi anak tunarungu agar menjadi lebih maksimalSecara umum proses yang dilakukan pada tahap requiment adalah menentukan tujuan media pembelajaran, menentukan konsep materi pembelajaran, dan menentukan konsep isi media pembelajaran.

b. Desain

Proses yang dilakukan pada tahap perancangan adalah perancangan materi, pembuatan flowchart dan pembuatan storyboard. Pada tahap perancangan dibutuhkan spesifikasi yang terperinci sehingga pada tahap selanjutnya tidak ragu dan diperlukan keputusan baru.

c. Implementasi

Implementasi media interaktif ini berisi tentang materi Perubahan Wujud Benda yang terdiri dari Kompetensi Dasar, materi, kuis, video pembelajaran dan profil pembuat media. Dalam media interaktif ini ada 5 menu yang berisikan tentang:

a. Kompetensi Dasar dan Indikator

Berisikan tentang kompetensi dasar tentang membedakan berbagai perubahan wujud benda berdasarkan Penyebabnya

b. Materi

Berisikan tentang materi perubahan wujud benda berdasarkan penyebabnya. Perubahan wujud benda ada tiga macam, yaitu perubahan wujud benda padat, benda cair dan gas.

c. Video

Berisikan materi perubahan wujud benda dalam bentuk video yang disertakan berupa contohnya

d. Kuis

Berisikan tentang soal soal perubahan wujud benda untuk bahan evaluasi siswa setelah menggunakan media pembelajaran interaktif

e. Profil

Berisi tentang informasi pembuat media belajar sendiri

d. Verification dan validasi

Berdasarkan Verification dan validasi akan membahas hasil validasi dari ahli media, ahli materi dan angket peserta didik diantaranya:

1) Nilai Hasil Validasi Media

Penilaian berdasarkan hasil analisis, diperoleh penilaian dari ahli media sebesar 33. Skor ini berdasarkan format penilaian keseluruhan 8 pernyataan menunjukan skor 82,5 dengan kriteria sangat baik. Dengan demikian,nilai ini berdasarkan penilaian ahli berada pada kriteria sangat baik

Tabel 2. Hasil Penilaian Ahli Media

\begin{tabular}{|c|c|c|c|c|}
\hline NO & Aspek penilaian & Deskriptor & Nilai & Total \\
\hline \multirow[t]{3}{*}{1} & \multirow[t]{3}{*}{ Tampilan Umum } & Desain media sesuai dengan materi IPA & 5 & \multirow{3}{*}{12} \\
\hline & & Desain media menarik dilihat & 4 & \\
\hline & & $\begin{array}{l}\text { Desain media menyajikan contoh perubahan } \\
\text { wujud benda }\end{array}$ & 3 & \\
\hline \multirow[t]{2}{*}{2} & \multirow[t]{2}{*}{ Tampilan Khusus } & Penilaian warna dalam media & 4 & \multirow[t]{2}{*}{8} \\
\hline & & Pemilihan media yang unik & 4 & \\
\hline
\end{tabular}




\begin{tabular}{|c|c|c|c|c|}
\hline \multirow[t]{3}{*}{3} & Penyajian Media & $\begin{array}{l}\text { Tampilan media menarik dan mudah } \\
\text { dibawa / dipindahkan }\end{array}$ & 4 & \multirow{3}{*}{13} \\
\hline & & Diberi judul atau keterangan media & 5 & \\
\hline & & $\begin{array}{l}\text { Penyajian media mampu mengembangkan } \\
\text { minat belajar siswa. }\end{array}$ & 4 & \\
\hline \multicolumn{4}{|c|}{ Jumlah } & 33 \\
\hline
\end{tabular}

2.)Nilai Hasil Validasi Materi

Berdasarkan tabel deskripsi data validasi aspek penilaian materi diperoleh jumlah skor $82 \%$. Maka materi yang akan digunakan dalam pembelajaran memiliki kategori Sangat Baik.

Tabel 3. Hasil Validasi Ahli Materi Pembelajaran

\begin{tabular}{|c|c|c|c|c|}
\hline No & Aspek Penilaian & Deskriptor & Nilai & Total \\
\hline \multirow[t]{4}{*}{1.} & \multirow[t]{4}{*}{ Relevansi } & $\begin{array}{l}\text { Materi relevan dengan kompetensi yang } \\
\text { harus dikuasai siswa }\end{array}$ & 4 & \multirow{4}{*}{18} \\
\hline & & $\begin{array}{l}\text { Media Interaktif Adobe Flash relevan } \\
\text { dengan kompetensi yang harus dikuasai }\end{array}$ & 5 & \\
\hline & & $\begin{array}{l}\text { Kelengkapan materi sesuai dengan } \\
\text { tingkat perkembangan siswa }\end{array}$ & 4 & \\
\hline & & $\begin{array}{l}\text { Materi cukup memenuhi tuntutan } \\
\text { kurikulum }\end{array}$ & 5 & \\
\hline \multirow[t]{2}{*}{2.} & \multirow[t]{2}{*}{ Keakuratan } & $\begin{array}{l}\text { Materi yang disajikan sesuai dengan } \\
\text { kebenaran keilmuan }\end{array}$ & 4 & \multirow{2}{*}{8} \\
\hline & & $\begin{array}{l}\text { Materi yang disajikan sesuai dengan } \\
\text { kehidupan sehari-hari }\end{array}$ & 4 & \\
\hline 3. & Kelengkapan sajian & $\begin{array}{l}\text { Menyajikan kompetensi yang harus } \\
\text { dikuasai siswa }\end{array}$ & 4 & 4 \\
\hline \multirow[t]{3}{*}{4.} & \multirow{3}{*}{$\begin{array}{l}\text { Kesesuaian } \\
\text { dengan sajian } \\
\text { pembelajaran tuntunan } \\
\text { terpusat pada siswa }\end{array}$} & Mendorong rasa keingintahuan siswa & 3 & \multirow{3}{*}{11} \\
\hline & & Mendorong terjadinya interaksi siswa & 4 & \\
\hline & & $\begin{array}{l}\text { Mendorong siswa membangun } \\
\text { pengetahuannya sendiri }\end{array}$ & 4 & \\
\hline \multicolumn{4}{|c|}{ Jumlah } & 41 \\
\hline
\end{tabular}

\section{f. Maintenance}

Media yang dibuat sudah layak digunakan sebagai media pembelajaran, khususnya bagi anak tunarungu. Media interaktif dapat membantu meningkatkan semangat belajar siswa karna, Tanpa media guru cenderung berbicara "satu arah" kepada siswa namun dengan adanya media guru dapat mengatur kelas sehingga siswa yang lebih banyak aktif. Media interaktif dapat menumbuhkan aktivitas siswa dalam pembelajaran yang tercermin dalam umpan balik siswa atau respon yang dipicu dengan adanya media interaktif oleh guru.

2. Deskripsi Hasil Peningkatan Kemampuan Belajar Peserta Didik

Hasil Peningkatan Kemampuan belajar peserta didik mengalami peningkatan setelah adanya media pembelajaran interaktif, Berdasarkan hasil diperoleh nilai rata rata dari hasil sebelum dan sesudah evaluasi pengaplikasian media video interaktif pembelajaran kepada responden kelas 4 SD yang berjumlah 10 orang dengan menghasilkan nilai rata rata 70,52\% sedangkan setelah menggunakan video interaktif nilai rata-rata menjadi $87,89 \%$ yang berada dalam kategori sangat baik. Berikut ini adalah tabel peningkatan nilai belajar sebelum dan sesudah menggunakan media pembelajaran interaktif: 
a. Data Nilai Sebelum Evaluasi

Tabel 4. Data Nilai Sebelum Evaluasi

\begin{tabular}{|c|c|c|c|}
\hline $\begin{array}{c}\text { Nama } \\
\text { Responden }\end{array}$ & Kelas & Nilai & Rata Rata \\
\hline GNP & IV. B & 52,63 & \multirow{10}{*}{70,52} \\
\hline$S$ & IV. B & 73,68 & \\
\hline FT & IV. B & 63,15 & \\
\hline MD & IV. B & 57,89 & \\
\hline A & IV. B & 78,94 & \\
\hline $\mathrm{MG}$ & IV. B & 68,42 & \\
\hline $\mathrm{NL}$ & IV. B & 84,21 & \\
\hline SL & IV. B & 94,73 & \\
\hline $\mathrm{AF}$ & IV. B & 57,89 & \\
\hline DFG & IV. B & 73,68 & \\
\hline \multicolumn{2}{|c|}{ Jumlah } & 705,22 & \\
\hline
\end{tabular}

b. Data Nilai Sesudah Evaluasi

Hasil data nilai sesudah evaluasi dapat dilihat pada table 5 di bawah ini

Tabel 5. Data Nilai Sesudah Evaluasi

\begin{tabular}{|c|c|c|c|}
\hline Nama Responden & Kelas & Nilai & Rata Rata \\
\hline GNP & IV. B & 94,73 & \multirow{10}{*}{87,89} \\
\hline $\mathrm{S}$ & IV. B & 94,73 & \\
\hline FT & IV. B & 68,42 & \\
\hline MD & IV. B & 84,21 & \\
\hline A & IV. B & 84,21 & \\
\hline $\mathrm{MG}$ & IV. B & 84,21 & \\
\hline $\mathrm{NL}$ & IV. B & 100 & \\
\hline SL & IV. B & 94,73 & \\
\hline $\mathrm{AF}$ & IV. B & 78,94 & \\
\hline DFG & IV. B & 94,73 & \\
\hline \multicolumn{2}{|c|}{ Jumlah } & 878,91 & \\
\hline
\end{tabular}

c.Gain Ternormalisasi

Berikut ini adalah nilai yang sudah diujikan menggunakan Gain Ternormalisasi sebagai berikut:

Tabel 6. Gain Ternormalisasi

\begin{tabular}{|c|c|c|c|c|c|c|c|c|}
\hline No & $\begin{array}{c}\text { Pre } \\
\text { Test }\end{array}$ & $\begin{array}{c}\text { Post } \\
\text { Test }\end{array}$ & $\begin{array}{c}\text { Skor } \\
\text { Maks }\end{array}$ & $\begin{array}{c}\text { Postest } \\
\text { Pretest }\end{array}$ & $\begin{array}{c}\text { Skor } \\
\text { Ideal } \\
\text { Pretest }\end{array}$ & $\begin{array}{c}\text { N } \\
\text { gain } \\
\text { Score }\end{array}$ & $\begin{array}{c}\text { N Gain } \\
\text { Score*100 }\end{array}$ & Keterangan \\
\hline 1. & 52,63 & 94,73 & 100 & 42,1 & 47,37 & 0,89 & 88,87 & Tinggi \\
\hline 2. & 73,68 & 94,73 & 100 & 21,05 & 26,32 & 0,80 & 79,98 & Tinggi \\
\hline
\end{tabular}




\begin{tabular}{|c|c|c|c|c|c|c|c|c|}
\hline 3. & 63,15 & 68,42 & 100 & 5,27 & 36,85 & 0,14 & 14,30 & Rendah \\
\hline 4 & 57,89 & 84,21 & 100 & 26,32 & 42,11 & 0,63 & 62,50 & Sedang \\
\hline 5 & 78,94 & 84,21 & 100 & 5,27 & 21,06 & 0,25 & 25,02 & Rendah \\
\hline 6 & 68,42 & 84,21 & 100 & 15,79 & 31,58 & 0,50 & 50,00 & Sedang \\
\hline 7 & 84,21 & 100 & 100 & 15,79 & 15,79 & 1,00 & 100,00 & Tinggi \\
\hline 8 & 94,73 & 94,73 & 100 & 0 & 5,27 & 0,00 & 0,00 & $\begin{array}{c}\text { Tidak } \\
\text { Terjadi } \\
\text { Peningkatan }\end{array}$ \\
\hline 9 & 57,89 & 78,94 & 100 & 21,05 & 42,11 & 0,50 & 49,99 & Sedang \\
\hline 10 & 73,68 & 94,73 & 100 & 21,05 & 26,32 & 0,80 & 79,98 & Tinggi \\
\hline \multicolumn{8}{|c|}{ Rata - rata Nilai } & \multicolumn{3}{|c|}{$\begin{array}{c}55,06 \\
\text { Sedang }\end{array}$} \\
\hline
\end{tabular}

Uji analisis untuk pembelajaran IPA materi perubahan wujud benda dan hasil belajar siswa menggunakan hasil pretest, posttes, gain dan N-gain. Gain adalah selisih antara nilai pretest dan posttest. Untuk menunjukkan kualitas peningkatan kemampuan belajar digunakan rumus rata-rata gain ternormalisasi. Kemudian $\mathrm{n}$ gain score diperoleh melalui pengurangan nilai postest dan pretest pada setiap responden, kemudian hasil tersebut dibagi dengan hasil penguran skor maksimal dikurangi skor pretest. Perlu diketahui bahwa skor maksimal diperoleh dari nilai tertinggi dari perolehan jawab responden pada pretest dan post test. Jadi Berdasarkan tabel diatas peningkatan kemampuan peserta didik bermacam-macam, untuk kategori tinggi berjumlah 4 orang, kategori sedang berjumlah 3 orang, kategori rendah berjumlah 2 orang dan terdapat 1 reponden yg tidak terjadi peningkatan sedikitpun. Jadi nilai rata-rata uji gain ternormalisasi yaitu 55,06 berada pada kriteria sedang.

\section{KESIMPULAN}

Berdasarkan uji coba peserta didik/responden, media pembelajaran ini masuk dalam kategori sangat baik karna penilaian dari ahli media menunjukan skor 82,5 , sedangkan dari ahli materi menunjukan skor 82 dan terbukti bahwa media pembelajaran interaktif dapat meningkatkan kemampuan belajar peserta didik yang awalnya nilai rata-rata peserta didik $(70,52)$ menjadi rata-rata skor keseluruhan aspek $(87,89)$ Sementara, kualitas peningkatan kemampuan belajar IPA dan hasil belajar siswa yang diperoleh melalui Uji Gain Ternormalisasi menunjukan rata-rata 55,06 dengan menunjukan kriteria sedang.

\section{DAFTAR PUSTAKA}

[1] Haenudin. 2013. Pendidikan Anak Berkebutuhan Khusus Tunarungu. Jakarta Timur. PT Luxima Metro Media

[2] Muhson,Ali 2010 Pengembangan media pembelajaran berbasis Teknologi Informasi,Jurnal pendidikan Akuntansi Indonesia Vol. VIII,1-10

[3] Ningsih, Fitri, Yulia .2019. Pengembangan Media PembelajaranTematik Berbasis Multimedia Interaktif untuk Meningkatkan Hasil Belajar Siswa Kelas IV Sekolah Dasar. Tesis. Program Studi Magister Keguruan Guru Sekolah Dasar Fakultas Keguruan dan Ilmu Pendidikan Universitas Bandar Lampung.

[4] Nismalasari, Santiani, Rohmadi, 2016, Penerapan Model Pembelajaran Learning Circle Terhadap Keterampilan Proses Sains dan Hasil Belajar Siswa Pada Pokok Bahasan Getaran Harmonis, Jurnal EduSains Vol. 4 No. 2 74-94

[5] Nafiah, Jumino, 2019 Efektifitas Brosur Sebagai Media Pendidikan Pemakai Untuk Meningkatkan Pengetahuan Temtang Perpustakaan Di SMA Negeri 3 Semarang, Jurnal Ilmu Perpustakaan, Vol 8 No.4 249-259

[6] Sartika, Maria Margareta. 2015. Meningkatkan Aktivitas dan Kemampuan Menyelesaikan Soal - Soal Operasi Hitung Campur Penjumlahan dan Pengurangan Melalui Model Pembelajaran Kooperatif Tipe Jigsaw 
Pada Peserta Didik Kelas III SD Santa Ursula Bandung. Skripsi, tidak diterbitkan, Fakultas Keguruan dan Ilmu Pendidikan, Universitas Pasundan Bandung.

[7] Sari,Sangosoko,2014 Media Interaktif Bahasa Inggris untuk Siswa Sekolah Dasar Kelas II, Jurnal Seminar Riset Unggulan Nasional Informatika dan Komputer FTI UNSA 2014 Vol 2 No 1 23-27

[8] Setia,Santi,Kurniawan, 2018 Pengembangan Media Pembelajaran Dengan Menggunakan Adobe Flash CS 6 Pada Materi Hukum Newton Tentang Gerak dan Penerapannya, Jurnal Edufisika Vol 3 no 1 56-67

\section{Biodata Penulis}

Vita Krisnita, memperoleh gelar sarjana pendidikan (S.Pd) Program Studi Pendidikan Teknologi Informasi Universitas Muhammadiyah Tasikmalaya lulus pada tahun 2020 .

Ir. Muhammad Taufiq, memperoleh gelar sarjana Teknik Perminyakan(S.T) lalu melanjutkan studi program magister manajemen dan magister teknik informatika( M.Kom) Saat ini sebagai Staf Pengajar Program Studi Pendidikan Teknologi Inforamsi Universitas Muhammadiyah Tasikmalaya (UMTAS).

Alfadl Habibie, memperoleh gelar sarjana pendidikan(S.Pd) Program Studi Pendidikan Bahasa Arab lulus tahun 2007, pada tahun 2013 memperoleh gelar Magister dari program studi Ilmu Pendidikan Islam UIN SGD Bandung. Saat ini sebagai Staf Pengajar Program Studi Pendidikan Teknologi Inforamsi Universitas Muhammadiyah Tasikmalaya (UMTAS). 